\title{
Building a Real-World Learning Community: The Work/Site Alliance of Southeastern Michigan (1)
}

\author{
Beverly Hunter; Dr. Yichun Xie \\ Piedmont Research Institute, 130 Mossie Lane, Amissville, VA 20106 \\ Tel: (540) 937-4038, Fax: (540) 937-2098 \\ Email: Bev_Hunter@PiedmontResearch.org
}

\begin{abstract}
Learning in the context of solving complex, real-world problems requires collaboration among diverse individuals and institutions and establishment of new learning communities. This session provides a framework for identifying the knowledge base required by an interdisciplinary, multi-institution program. The framework identifies the locus of knowledge across groups of participants in the learning community. Examples are provided of participant roles as learners, teachers, and builders of new knowledge. (1)
\end{abstract}

Keywords: learning communities; distributed learning environments; lifelong learning; systemic reform.

\section{Creating an Alliance for Learning and Community Development}

In order to understand learning in new, organizationally complex situations, researchers and practitioners will need to shift focus from certain aspects of traditional school and classroom models to a framework that more accurately reflects the dynamics of these new settings. Most important in this shift of focus are our concepts about who are the learners and teachers, and what is the locus of knowledge. A real-world, or "authentic" context for learning requires interactions among people of varying ages, backgrounds, and institutions (Hunter \& Goldberg, 1995; Gerstner et al, 1994; Collins, Brown \& Newman, 1989). For new learning communities to succeed, each member of the community must play multiple roles as learner, teacher, and creator of new knowledge. This session provides a framework for one such context -- the Work/Site Alliance.

The Work/Site Alliance (W/SA) began in 1997 in the greater Detroit area of southeastern Michigan (counties of Wayne, Washtenaw, and Oakland). The W/SA vision is an outgrowth of pioneering work by Randall Raymond, then a high school biology teacher at Detroit's Cass Tech high school, and his students. W/SA enables students and teachers at high schools, community colleges and 4-year institutions, along with employees of municipal and county government agencies, to develop skills and knowledge in applications of geospatial technologies while they are working on real projects of importance to their local communities. The W/SA institutions currently include Henry Ford Community College in Dearborn; Eastern Michigan University in Ypsilanti; several high schools in the region; County and municipal government agencies; and private industry firms. The projects use geospatial information technologies (GIT) to integrate and analyze data in a geographic representation that shows interactions among various types of information such as land ownership, environmental conditions, demographics, buildings, and economic information. Example projects involve Brownfields inventory for Detroit economic development, census tract delineation, parks and recreation facilities information system, epidemiology studies, facilities management for Detroit Public Schools; historic buildings database for Corktown Economic Development Commission and Detroit 300 Anniversary.

GIT (also referred to as Geographic Information Systems) is a rapidly growing interdisciplinary field with applications in many areas of endeavor, from earth and space sciences, to urban planning and management, to environmental research and engineering, to law enforcement, to many kinds of businesses, industry, and government operations. As a result of this rapid development, there are not enough people with skills and knowledge in GIT to meet the demands for its applications in government, industry, and community-based organizations.

\section{Intended Benefits from the W/SA Model}

The founders of the W/SA hoped that several types of synergies and benefits would result from this collaborative effort. High school and undergraduate students would have opportunities to learn marketable skills in GIT. Working with data from their local communities and environments would be motivating to students, building 
upon their existing knowledge. Visual, spatial representations of data would motivate and enable a wider range of students to participate in analytic and problem-solving tasks. Municipal and county government agencies would benefit from the combination of expertise of university-based GIT technologists, plus the affordable talents of students to work on projects for the community. Local engineering firms would have a source of technically skilled labor to hire. Educational institutions would modernize curriculum offerings and technical capacity. Overall, economic development of the community would result.

One example of this synergy involves urban brownfields. Brownfields are unused parcels of land that are designated by the Environmental Protection Agency as environmentally contaminated by some prior use, such as industrial plants. Brownfields are an economic and environmental detriment to the quality of the city. High school and middle school students worked with the Wayne County Department of Jobs and Economic Development and the EMU CEITA technologists to develop a Brownfields Information System. This system integrates into one Detroit map information about parcels ownership and brownfields contamination, with digital photographs and dynamic visual walk-through of the property. This system can be used by city and county officials in their efforts to obtain industry investment in clean-up and re-use of these properties. The benefits of this project included the following: the county office obtained a high-quality prototype system in exchange for a relatively small contract price; the schools obtained experience and skill in building a GIS application; in addition to technical skills, students gained knowledge of environmental and economic conditions in their neighborhoods; and Alliance management addressed issues of contractual relationships, GIS database development, project management, and quality control.

\section{Constructing a Framework for Learning in the Work/Site Alliance}

In order for the intended W/SA synergies and benefits to materialize, the collective Alliance needs to foster learning by all of its members. The individual and institutional members of the W/SA address social, political, financial, technical, pedagogical, cognitive, curricular and organizational issues simultaneously as they shape real community problem situations into GIT projects that provide both solutions to the problem and contexts for learning and teaching. Programs and projects that are multi-institutional and interdisciplinary are likely to become more common in education, following trends in post-industrial society more generally. Whenever the regularities of traditional schooling give way to new arrangements, it will be useful to establish a provisional framework for learning at the outset. Such a framework will make explicit the kinds of learning needed to achieve the goals of the collective, locus of existing knowledge base, and expectations about the learning and teaching roles of each member.

\section{Identifying Skills and Knowledge Needed Across the Overall Collaboration}

Growth, sustainability and institutionalization of new models such as the W/SA demands that the

collective enterprise build certain kinds of knowledge. In other words, knowledge is instrumental in the achievement of community goals (e.g. quality of life, environmental quality, economic development) as well as being a valued academic outcome in its own right. Successful functioning of the W/SA requires the continual creation and application of four main categories of skill and knowledge. These categories include technology and information handling; interdisciplinary problem domains; project management; and organizational development.

\section{Technology-Related Skills and Knowledge Required}

The power of the GIT technology and its applications is a strong motivator among all Alliance members. To take advantage of the technology requires a range of technical and information-handling skills and knowledge. The technology and its applications are currently in a state of rapid change, which means that any person desiring to apply the technological tools needs continual updating of their skills. The W/SA organizes these skills and knowledges at three levels: operations, applications, and technical management. Illustrative areas of skill and knowledge for the GIT operations level include: operating GIS /Mapping software such as ArcView or MapInfo; digitizing and editing digital maps and aerial photographs; registering/rectifying images; operating plotters or map production equipment; using a spreadsheet database system for tabular data entry. The GIS application level requires skills in using GIS software to produce maps and other representations of information for specific uses; conducting spatial analysis; using a database management system; creating data models; programming in a language such as Visual Basic. For management or administration of GIS systems, illustrative areas of skill and knowledge include: expert-level use of GIS software; customizing GIS software with macros; customizing userinterfaces for a GIS application; Visual Basic/C++ programming; Internet application development/Java scripting; writing user manuals and metadata; training end users. 


\section{Subject-Matter Knowledge Required}

Each community-based problem or project requires the creative application of knowledge and expertise in interdisciplinary domain of the problem to be solved. As Pryor \& Soloway (undated) point out, when students are involved in real-world research and problem solving, understanding the content is a necessary part of the process rather than only an end goal. Example fields include law enforcement, economic development, water pollution, historic neighborhoods conservation, public information systems, facilities management. For a particular community-based project, a more detailed analysis of required knowledge would identify domains within each of the four categories of knowledge. For example in the W/SA crime mapping project, expertise was needed in the areas of law enforcement, social services, and community policing, as well as the specific GIT techniques -- such as geocoding addresses -- needed for that application.

\section{Project Management Skills Required}

A third category of skill and knowledge needed in this Alliance is the discipline of project management. Participants need to learn how to manage projects both within their own institution and with team members from other institutions. Project management includes such skills as analyzing and articulating project requirements, setting up implementation procedures, establishing and meeting tasks and milestones, forming and coordinating project teams, managing financial and other resources, providing leadership, and ensuring quality.

\section{Organizational Development Knowledge and Expertise Required}

A fourth category is organizational development and institutional change. Building new, complex organizational alliances requires knowledge and skills in areas such as team-building, communications, management, leadership, politics, development of policies and procedures, and finance.

\section{Identifying W/SA Participant Groups}

Each individual brings a particular set of skills, knowledge and purposes to the collective endeavor. For planning, analysis, and administrative purposes, it is convenient to group participants in terms of their institution type and position in the institution. W/SA includes the following groups: K-12 teachers (actually, grades 7 - 12); grades 7 -12 students; undergraduate faculty from a variety of disciplines and programs; undergraduate students; university-based GIS technologists; educational administrators; government agency staff; and private industry partners.

The secondary school and undergraduate faculty in the W/SA teach a wide range of subjects, including English, language arts, business, technology, all natural and social sciences, mathematics, geography, history, and professional areas such as criminal justice, urban planning, and environmental engineering. In the ideal case, subject-matter expertise of faculty is matched to the specific problem area being addressed for government or industry clients. The "educational administrators" group also includes a wide range of individuals, such as a school district science coordinator, a school system strategic planner, the director of a vocational education center, high school principals, community college administrators, and others. Government agency clients include staff and administrators in municipal and county government agencies such as economic development, parks and recreation, environment, transportation, law enforcement. In multi-institution programs that include research in the learning sciences, researchers would be included in this list of participant groups.

Table 1 provides examples of the types of knowledge and teaching roles that each of these participant groups provides to the overall W/SA community, within the four categories of skill and knowledge identified above. When designing a multi-institution educational program it is useful to identify the overall knowledge base required and to inventory the sources of those needed knowledge components across the participant groups. Such an analysis serves several purposes. First, it can help to communicate among the participating groups what their expected contributions are to the collective knowledge base. Secondly, it can assist in identifying missing areas of needed expertise that should be added to the mix of participants. Thirdly, in defining any new project for the Alliance to undertake, a more detailed analysis along these lines helps to identify institutions, individuals, teams, and roles to include in that specific project. 
Table 1. Example knowledge contributions and teaching roles of W/SA participant groups.

\begin{tabular}{|c|c|c|c|c|}
\hline $\begin{array}{l}\text { Work/Site Alliance } \\
\text { Participant Groups }\end{array}$ & $\begin{array}{c}\text { Technology \& } \\
\text { Information } \\
\text { Skills }\end{array}$ & $\begin{array}{l}\text { Subject-matter } \\
\text { Knowledge }\end{array}$ & $\begin{array}{c}\text { Project } \\
\text { Management } \\
\text { Expertise }\end{array}$ & $\begin{array}{c}\text { Organizational } \\
\text { Development }\end{array}$ \\
\hline K-12 teachers & Pedagogy & $\begin{array}{l}\text { Curriculum } \\
\text { integration }\end{array}$ & $\begin{array}{l}\text { Organizing } \\
\text { student teams } \\
\text { and roles }\end{array}$ & \\
\hline K-12 students & Peer coaching & $\begin{array}{l}\text { Learning and } \\
\text { proving through } \\
\text { projects }\end{array}$ & & \\
\hline $\begin{array}{l}\text { Undergraduate } \\
\text { faculty }\end{array}$ & $\begin{array}{l}\text { Learning through } \\
\text { training }\end{array}$ & $\begin{array}{c}\text { Subject-matter } \\
\text { knowledge; } \\
\text { course integration }\end{array}$ & $\begin{array}{l}\text { Student teams } \\
\text { and roles }\end{array}$ & $\begin{array}{l}\text { (Should include } \\
\text { specialists in org. } \\
\text { development). }\end{array}$ \\
\hline $\begin{array}{l}\text { Undergraduate } \\
\text { students }\end{array}$ & Peer coaching & $\begin{array}{l}\text { Learning and } \\
\text { proving through } \\
\text { projects }\end{array}$ & & \\
\hline $\begin{array}{l}\text { University GIS } \\
\text { technologists }\end{array}$ & $\begin{array}{l}\text { Design of applica- } \\
\text { tions; Technical } \\
\text { training of } \\
\text { participants }\end{array}$ & & $\begin{array}{c}\text { Application } \\
\text { design; Data } \\
\text { modeling; Qual- } \\
\text { ity assurance } \\
\end{array}$ & \\
\hline $\begin{array}{l}\text { Educational } \\
\text { Administrators }\end{array}$ & & $\begin{array}{l}\text { Academic } \\
\text { curriculum } \\
\text { requirements }\end{array}$ & & $\begin{array}{l}\text { policy con- } \\
\text { straints, options, } \\
\text { resources }\end{array}$ \\
\hline $\begin{array}{l}\text { Government } \\
\text { agency clients \& } \\
\text { Industry partners }\end{array}$ & Job requirements & $\begin{array}{c}\text { Real-world } \\
\text { problem situation }\end{array}$ & $\begin{array}{c}\text { Project } \\
\text { requirements; } \\
\text { data sources }\end{array}$ & \\
\hline
\end{tabular}

\section{Identifying Learning Outcomes}

In traditional school and classroom contexts for learning, both researchers and practitioners typically focus on learning processes and outcomes for K-12 students. More complex multi-institution programs such as the W/SA need to address processes and learning outcomes for all participant groups. Success of the program depends upon continual learning by all members. Table 2 shows some example types of learning outcomes for W/SA groups within the four categories of skill and knowledge discussed above. Such a framework for learning outcomes could be established in the form of learning goals, and also used as an evaluation framework as the program develops.

\section{Arranging Multiple Venues for Learning and Teaching}

Because the overall learning community is mutually interdependent for its sources of knowledge and expertise, the various participant groups need to arrange opportunities to teach and learn from the other participant groups. The W/SA has addressed this need by organizing activities such as workshops, conferences, and project meetings at a variety of locations including the community college, university, high schools, client offices, public meetings, and professional conferences. For example, a government staff person may conduct a training session at a high school lab for teachers and students. A team of technologists, teachers and students may demonstrate their project progress and findings at a client's offices or at a public meeting. Many projects involve field data collection, requiring technical and subject-matter instruction at the field site. While arranging multiple venues for learning imposes logistical challenges (particularly when equipment and software are needed), it is essential to building a learning community across institutions with different cultures.

In addition to multiple venues for learning and teaching, the groups prefer different pedagogical approaches. Real-world practitioners and professionals typically want problem solutions highly specific to their immediate project. High school teachers, on the other hand, have preferred to learn through a series of mini-projects that gradually introduce particular techniques or content. From a teaching standpoint, the university technologists and faculty generally adopt a more didactic approach than high school teachers who have tended to use more 
inquiry-based approaches.

One challenge for the W/SA has been to capture and weave together the many threads and sources of expertise and knowledge in a form that can be communicated for future projects and participants to learn from. This is taking the form of project case studies. Each case study is organized around a particular type of community problem-solving project, such as crime mapping, agricultural land preservation, brownfields inventory, and recreation facilities information system. A case study combines hands-on training in GIT techniques for that application using the project data sets, with application problem-solving, project management, and instructional management techniques and exercises derived from the W/SA project experiences (Work/Site Alliance, 2000).

Table 2. Example learning outcomes of W/SA participant groups.

\begin{tabular}{|c|c|c|c|c|}
\hline $\begin{array}{c}\text { Work/Site Alliance } \\
\text { Institutions \& } \\
\text { Individuals }\end{array}$ & $\begin{array}{l}\text { Technology \& } \\
\text { Information } \\
\text { Skills }\end{array}$ & $\begin{array}{l}\text { Subject-matter } \\
\text { Knowledge }\end{array}$ & $\begin{array}{c}\text { Project } \\
\text { Management } \\
\text { Expertise }\end{array}$ & $\begin{array}{c}\text { Organizational } \\
\text { Development }\end{array}$ \\
\hline K-12 teachers & $\begin{array}{c}\text { Data manage- } \\
\text { ment; data mod- } \\
\text { eling; spatial } \\
\text { analysis } \\
\end{array}$ & $\begin{array}{l}\text { Real-world } \\
\text { applications and } \\
\text { methods of } \\
\text { investigation }\end{array}$ & $\begin{array}{l}\text { Managing } \\
\text { student } \\
\text { teamwork }\end{array}$ & $\begin{array}{l}\text { Teacher team } \\
\text { collaborations; }\end{array}$ \\
\hline K-12 students & $\begin{array}{l}\text { Data collection; } \\
\text { spatial analysis; } \\
\text { multimedia } \\
\text { integration }\end{array}$ & $\begin{array}{c}\text { Real-world } \\
\text { applications of } \\
\text { academic subjects }\end{array}$ & $\begin{array}{c}\text { Teamwork \& } \\
\text { collaboration; } \\
\text { quality assurance }\end{array}$ & \\
\hline $\begin{array}{l}\text { Undergraduate } \\
\text { faculty }\end{array}$ & $\begin{array}{l}\text { Data manage- } \\
\text { ment; data mod- } \\
\text { eling; spatial } \\
\text { analysis } \\
\end{array}$ & $\begin{array}{l}\text { GIT methods \& } \\
\text { applications in } \\
\text { their discipline }\end{array}$ & $\begin{array}{l}\text { Managing } \\
\text { student } \\
\text { teamwork }\end{array}$ & \\
\hline $\begin{array}{l}\text { Undergraduate } \\
\text { students }\end{array}$ & $\begin{array}{c}\text { Data collection; } \\
\text { spatial analysis; } \\
\text { multimedia } \\
\text { integration } \\
\end{array}$ & $\begin{array}{c}\text { Real-world } \\
\text { applications of } \\
\text { academic subjects }\end{array}$ & $\begin{array}{l}\text { Teamwork \& } \\
\text { collaboration; } \\
\text { quality assurance }\end{array}$ & \\
\hline $\begin{array}{l}\text { University GIS } \\
\text { technologists }\end{array}$ & Pedagogy & & $\begin{array}{l}\text { Design of W/SA } \\
\text { projects }\end{array}$ & $\begin{array}{l}\text { Communications; } \\
\text { team-building; } \\
\text { local politics }\end{array}$ \\
\hline $\begin{array}{l}\text { Educational } \\
\text { administrators }\end{array}$ & $\begin{array}{l}\text { Awareness of GIT } \\
\text { applications; } \\
\text { requirements for } \\
\text { tech infrastructure }\end{array}$ & $\begin{array}{c}\text { Awareness of GIT } \\
\text { roles in subject } \\
\text { areas }\end{array}$ & & $\begin{array}{c}\text { Faculty devel- } \\
\text { opment strategies; } \\
\text { managing } \\
\text { partnerships }\end{array}$ \\
\hline $\begin{array}{l}\text { Government } \\
\text { agency clients \& } \\
\text { Industry partners }\end{array}$ & & $\begin{array}{l}\text { GIT application } \\
\text { design }\end{array}$ & & $\begin{array}{l}\text { Feasible roles for } \\
\text { schools in projects; } \\
\text { local politics }\end{array}$ \\
\hline
\end{tabular}

\section{W/SA Presenters at ICLS Special Session}

Members of this panel will elaborate on the framework described above, from their perspectives and experiences as teachers, students, administrators, clients and researchers.

Beverly Hunter, the panel organizer and moderator serves as a senior advisor and strategist for the W/SA. She will introduce the framework described above and some implications for designing and conducting research in innovative educational experiments.

Randall Raymond is the visionary science teacher from Detroit's Cass Tech High School who empowered his students with GIT skills. Students were then able to work on projects for clients in government, community organizations, and corporations. Raymond's precedent at Cass Tech was the inspiration for the Work/Site Alliance and the "proof of concept" that has engendered support for the W/SA model. Now the GIS Director for the Office 
of Strategic Planning in Detroit Public School system, Raymond will describe the learning opportunities inherent in community problem solving with geospatial information technologies.

Dr. Yichun Xie is Director of the Center for Environmental Information Technology Applications (CEITA) at Eastern Michigan University. CEITA is the technical hub of the Work/Site Alliance and serves all member institutions by analyzing client needs, defining GIT projects, establishing project teams, teaching users, developers and teachers at all levels, and providing quality assurance on projects. Xie will describe the GIT technology skills and concepts needed for community problem- solving projects and show how these skills are distributed and built among teams of people at different levels of education and institutional settings. Xie will explain the technical and organizational conditions under which real-world projects can serve as context for technology skill learning at the various levels of education.

Dr. Nasreen Jalili is a teacher of chemistry at Cody High School in Detroit. Jalili is one of several teachers at Cody who have been learning GIT skills, applying GIT tools to her curriculum, engaging her students in GIT projects, and is now teaching other teachers these skills and applications. She will explain how the use of the GIT technologies and project-based learning support her pedagogical strategies.

Stuart Waddell is Director of Social Science Division at Henry Ford Community College in Dearborn, Michigan. Waddell is Principal Investigator for the W/SA project. He will identify institutional, cultural, financial and curricular factors that have affected the community college's ability to take advantage of new technology-driven career fields for the benefit of its student population.

Tiffany Williams and Kathryn Carter are seniors at Cass Tech High School in Detroit. They will discuss the GIS projects they have been working on and what they have been learning in this process.

Alan Roth, Technical Consultant for Geographic Information Systems, Wayne County Department of Public Services has worked with teachers and students at Cody High School in Detroit as the client for some of their community service projects. One transportation mapping project involves the students in quality assurance procedures to check on the quality of imagery provided by the primary contractor for every road and street in the County. Roth will describe the characteristics of GIS projects suitable for student work, and the roles he and his colleagues play in training the students and overseeing the projects.

\section{Endnotes}

(1) This work is supported in part by the National Science Foundation Advanced Technology Education program Grant No. 9752086 to Henry Ford Community College.

\section{References}

Collins, A., Brown, J. S., \& Newman, S. E. (1989). Cognitive apprenticeship: Teaching the crafts of reading, writing, and mathematics. In L. B. Resnick (Ed.), Knowing, learning, and instruction: Essays in honor of Robert Glaser (pp. 453-494). Hillsdale, NJ: Erlbaum.

Gerstner, L., Semerad, R., Doyle, D., \& Johnston, W. (1994). Reinventing Education. New York: Penguin Books.

Hunter, B. \& Goldberg, B. (1995). Learning and teaching in 2004: The BIG DIG. In U.S. Congress, Office of Technology Assessment, Education and Technology, Future Visions. OTA-BP-EHR-169. Washington, DC: U.S. Government Printing Office.

Pryor, A. \& Soloway, E. (undated). Foundations of science: Using technologies to support authentic sciene learning. Univ. Michigan Hi-C Research. http://www.hi-ce.org/papers/foundations_of_science_using/index.html

Work/Site Alliance (2000). Case study applications of GIS for educators. http://ceita.acad.emich.edu/wsatraining 